\title{
Viscosity of BOF Slag
}

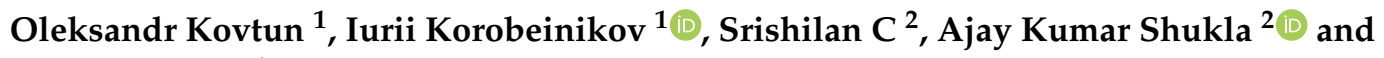 \\ Olena Volkova ${ }^{1, *}$
}

1 Technical University Bergakademie Freiberg, Institute of Iron and Steel Technology, Leipziger Straße 34, 09599 Freiberg, Germany; Oleksandr.Kovtun@student.tu-freiberg.de (O.K.);

Iurii.Korobeinikov@iest.tu-freiberg.de (I.K.)

2 Department of Metallurgical and Materials Engineering Chennai, Indian Institute of Technology, IIT Madras, Chennai 600036, India; srishilan0chetlur@gmail.com (S.C.); shukla@iitm.ac.in (A.K.S.)

* Correspondence: volkova@iest.tu-freiberg.de; Tel.: +49-373-139-3100

Received: 24 June 2020; Accepted: 19 July 2020; Published: 21 July 2020

\begin{abstract}
The viscosities of the industrial basic oxygen furnace (BOF) slag with varying compositions of $\mathrm{MgO}, \mathrm{Al}_{2} \mathrm{O}_{3}, \mathrm{TiO}_{2}$, and $\mathrm{MnO}$ were continuously measured at a temperature range between 1400 and $1700^{\circ} \mathrm{C}$ using the rotating bob method. Three characteristic temperatures for the melting behavior of the BOF slag were investigated using a high-temperature microscope. The solid fraction of the slag was calculated by FactSage 7.2 using the FTOxid database. General observations from the experimental data show that the increase in $\mathrm{MgO}$ tends to increase viscosity. However, $\mathrm{Al}_{2} \mathrm{O}_{3}, \mathrm{TiO}_{2}$, and $\mathrm{MnO}$ decrease viscosity up to a certain level, and beyond that, they also increase the viscosity. The measured values of the viscosity of BOF slags were compared and discussed with known data from the literature. Finally, the activation energy of $\mathrm{BOF}$ slags with different compositions of $\mathrm{MgO}$, $\mathrm{Al}_{2} \mathrm{O}_{3}, \mathrm{TiO}_{2}$, and $\mathrm{MnO}$ was calculated in the temperature range of industrial operations.
\end{abstract}

Keywords: viscosity; slag; $\mathrm{BOF} ; \mathrm{FeO} ; \mathrm{TiO}_{2} ; \mathrm{Al}_{2} \mathrm{O}_{3} ; \mathrm{MnO}$; solid fraction

\section{Introduction}

The growing industrialization has paved the way for a tremendous increase in iron and steel production. This has also given the rise the large quantity of the slag. Slag-the by-product of the iron and steel industry-has several functions namely, (1) desulfurization, (2) dephosphorization, (3) separation of the non-metallic inclusions, (4) removal of the tramp elements, and (5) minimization of the heat loss. Slags from the iron and steel industry are usually classified as blast furnace (BF) slag, basic oxygen furnace (BOF) slag, electric arc furnace (EAF) slag, secondary metallurgical slag (ladle slag), tundish slag, and mold powder. The chemical composition of the metallurgical slags varied with respect to the steel grades produced, the input materials, and the purpose of treatment. All the metallurgical processes that occur between the slag and the liquid metal are dependent on their thermophysical properties such as viscosity, density, and surface tension. Thus, it becomes crucial to study these properties beforehand to control the process efficiently.

Various researchers have tried to estimate, predict, or measure the viscosity of slag through experimental or modeling routes. Several models for predicting the viscosity especially of the metallurgical slag have been developed in the past; for example, it starts with the earliest available Urbain model [1] for any slag system, followed by the quasi-chemical viscosity model for fully liquid slags in an $\mathrm{Al}_{2} \mathrm{O}_{3}-\mathrm{CaO}-\mathrm{FeO}-\mathrm{MgO}-\mathrm{SiO}_{2}$ system [2], quasi-chemical viscosity model for partly crystallized and fully liquid slags in an $\mathrm{Al}_{2} \mathrm{O}_{3}-\mathrm{CaO}-\mathrm{FeO}-\mathrm{SiO}_{2}$ system [3,4], quasi-chemical viscosity model for fully liquid slag in an $\mathrm{Al}_{2} \mathrm{O}_{3}-\mathrm{CaO}-\mathrm{MgO}-\mathrm{SiO}_{2}$ system [5,6], structurally based viscosity model for fully liquid slags in a $\mathrm{CaO}-\mathrm{MgO}-\mathrm{Al}_{2} \mathrm{O}_{3}-\mathrm{FeO}-\mathrm{SiO}_{2}$ system [7], a model based on the optical basicity [8], model based on a new definition of the basicity ratio close to Bell's basicity [9], and finally 
the KTH (Kungliga Tekniska Hoegskolan Stockholm) model based on the Eyring equation [10]. All the above models start with relating the viscosity to the bridging and non-bridging oxygen atoms available in the respective oxide ion. Kozhukhov has calculated the BOF slag viscosity using the polymer model [11]. Liu et al. have reviewed and critically assessed the viscosity models of heterogeneous fluids [12]. Jiao et al. have used the multiphase equilibrium to investigate and report the viscosity and liquidus temperature of the blast furnace slag as a function of $\mathrm{MgO}, \mathrm{Al}_{2} \mathrm{O}_{3}, \mathrm{CaO} / \mathrm{SiO}_{2}$, and $\mathrm{FeO}$ content [13].

The studies related to the viscosity of several FeO-containing oxide systems are available in the literature. Kondratiev et al. have given a perfect overview of the existing measurements for the viscosity of $\mathrm{FeO}-\mathrm{MgO}-\mathrm{SiO}_{2}, \mathrm{CaO}-\mathrm{FeO}-\mathrm{MgO}-\mathrm{SiO}_{2}$ and $\mathrm{Al}_{2} \mathrm{O}_{3}-\mathrm{CaO}-\mathrm{FeO}-\mathrm{MgO}-\mathrm{SiO}_{2}$ oxide systems. [14]. Most of the viscosity measurements in the past were carried out using the rotating cylindrical method, with Fe or Mo crucibles, under $\mathrm{Ar}, \mathrm{N}_{2}$, or $\mathrm{CO} / \mathrm{CO}_{2}$ atmosphere. The viscosity of synthetic $\mathrm{SiO}_{2}-\mathrm{FeO}-\mathrm{CaO}$ slags was measured as a function of $\mathrm{CaO} / \mathrm{FeO}$ ratio using the molybdenum crucibles [15]. The viscosity of $\mathrm{CaO}-\mathrm{SiO}_{2}-\mathrm{Fe}_{2} \mathrm{O}_{3}-\mathrm{MnO}-\mathrm{MgO}-\mathrm{Al}_{2} \mathrm{O}_{3}$ slags $\left(\mathrm{CaO} / \mathrm{SiO}_{2}=0.4-1.2\right)$ was measured as functions of iron oxide content and basicity, using the rotating crucible method with $\mathrm{Pt}$-20Rh crucible, under the ambient air atmosphere [16]. Lee et al. have measured the viscosity of BF slags $\left(\mathrm{CaO} / \mathrm{SiO}_{2}=1.15-1.6\right)$ as a function of $\mathrm{FeO}$ [17]. Liu et al. have investigated the influence of $\mathrm{V}_{2} \mathrm{O}_{3}$ content on the viscosity of $\mathrm{FeO}-\mathrm{SiO}_{2}-\mathrm{V}_{2} \mathrm{O}_{3}-\mathrm{TiO}_{2}$ slags [18]. Huang et al. have reported the effect of $\mathrm{Cr}_{2} \mathrm{O}_{3}$ on the viscosity of $\mathrm{CaO}-\mathrm{SiO}_{2}-\mathrm{FeO}-\mathrm{MgO}-\mathrm{MnO}-\mathrm{Cr}_{2} \mathrm{O}_{3}$ slags [19]. The influence of temperature, slag basicity, and $\mathrm{Cr}_{2} \mathrm{O}_{3}$ content on the viscosity of stainless steelmaking slags has been experimentally determined by Liu et al. [20]. The viscosity of FeO-containing nickel slag was investigated as a function of $\mathrm{FeO} / \mathrm{Al}_{2} \mathrm{O}_{3}$ ratio and of $\mathrm{Al}_{2} \mathrm{O}_{3} / \mathrm{SiO}_{2}$ ratio by Zhang and co-workers [21,22]. The influence of $\mathrm{TiO}_{2}$ content between 5 and $15 \mathrm{wt} \%$ on the viscosity of the $\mathrm{BF}$ slags was investigated by Jiao and co-workers, using the rotating viscometer. Thereby, the viscosity of investigated $\mathrm{BF}$ slags decreases with increasing $\mathrm{TiO}_{2}$ content $[23,24]$. The viscosity of $\mathrm{BF}$ slag was examined as a function of $\mathrm{TiO}_{2}$ and $\mathrm{Al}_{2} \mathrm{O}_{3}$ content in [25] and as a function of $\mathrm{MgO}$ and $\mathrm{Al}_{2} \mathrm{O}_{3}$ in [26,27].

$\mathrm{BOF}$ slags differ from all other iron or steelmaking $\mathrm{FeO}$-containing slags due to their high $\mathrm{FeO}$ content and high $\mathrm{CaO} / \mathrm{SiO}_{2}$ ratio. Only five studies exist that are related to the viscosity of the BOF slags or slag with the compositions close to that of $\mathrm{BOF}$ slag, which are reported in the literature [28-32]. The viscosities of highly basic synthetic slags $\left(\mathrm{CaO}-\mathrm{SiO}_{2}-\mathrm{FeO}-\mathrm{MgO}\right.$ and $\left.\mathrm{CaO}-\mathrm{SiO}_{2}-\mathrm{FeO}-\mathrm{Al}_{2} \mathrm{O}_{3}-\mathrm{MgO}\right)$ were measured using a rotating viscosimeter in Pt-12 mass\%Rh crucible in order to prevent the contamination of slags by crucible materials. Thereby, the influence of a solid fraction on the viscosity was examined [28]. The viscosity of highly basic $\mathrm{CaO}-\mathrm{MgO}-\mathrm{SiO}_{2}-\mathrm{Al}_{2} \mathrm{O}_{3}-\mathrm{FeO}$ synthetic slag was measured as functions of $\mathrm{FeO}$ and $\mathrm{Al}_{2} \mathrm{O}_{3}$ contents using the rotating cylinder method [29]. The viscosity of heterogeneous industrial BOF slag containing 2.37-2.41 wt \% of $\mathrm{MgO}$, and content of $\mathrm{P}_{2} \mathrm{O}_{5}, \mathrm{MnO}$, $\mathrm{V}_{2} \mathrm{O}_{5}, \mathrm{Cr}_{2} \mathrm{O}_{3}$, and $\mathrm{TiO}_{2}$ that is typical for the BOF process level was measured using the rotational-type viscometer with a molybdenum crucible under the argon atmosphere. The new parameters of the Einstein-Roscoe equation for the relative viscosity calculation were found using the viscosity simulations in FactSage [30]. Liu et al. examined further the industrial BOF slag viscosity as functions of added $\mathrm{SiO}_{2}$ and $\mathrm{Al}_{2} \mathrm{O}_{3}$ content, in the temperature range between 1500 and $1700^{\circ} \mathrm{C}$. It was found that $\mathrm{Al}_{2} \mathrm{O}_{3}$ and $\mathrm{SiO}_{2}$ lead to a decrease in the fraction of solid phases, thus decreasing the viscosity. At the same time, they also increase the viscosity by the formation of a network [31]. Liu and co-workers, in their further research, observed the BOF slag crystallization behavior in situ at high temperatures using a confocal laser scanning microscope. The results have shown that the abrupt increase in the viscosity occurs only when the crystal fraction exceeds a critical volume fraction of solid. The critical solid fraction varies between 0.33 and 0.51 for the investigated slags [32].

The viscosity tests were also carried out along with structural analysis after the viscosity measurements of the cold quenched slag samples. Three crystalline phases—namely $\mathrm{Fe}_{2} \mathrm{TiO}_{4}, \mathrm{Fe}_{2} \mathrm{SiO}_{4}$, and $\mathrm{FeV}_{2} \mathrm{O}_{4}$-were found in $\mathrm{FeO}-\mathrm{SiO}_{2}-\mathrm{V}_{2} \mathrm{O}_{3}-\mathrm{TiO}_{2}$ slag, using XRD [18]. Liu et al. used scanning electron microscope with energy-dispersive $X$-ray spectroscopy SEM/EDS in order to evaluate the 
quantity of secondary phases, e.g., spinel particles, during the viscosity measurement of the stainless steelmaking slags [20]. The structure of FeO-containing nickel slag was analyzed by Fourier transform infrared spectroscopy (FTIR) and Raman spectroscopy in [21,22]. The effect of $\mathrm{TiO}_{2}$ and $\mathrm{FeO}$ [24], $\mathrm{TiO}_{2}$ and $\mathrm{Al}_{2} \mathrm{O}_{3}$ [25], and $\mathrm{MgO}$ and $\mathrm{Al}_{2} \mathrm{O}_{3}[26,27]$ on the structure of $\mathrm{BF}$ slag was investigated using FTIR and Raman analysis. In [29], the effect of $\mathrm{Al}_{2} \mathrm{O}_{3}$ and $\mathrm{FeO}$ contents on the structure of highly basic $\mathrm{CaO}-\mathrm{MgO}-\mathrm{SiO}_{2}-\mathrm{Al}_{2} \mathrm{O}_{3}-\mathrm{FeO}$ slag was also analyzed using FTIR.

The viscosity studies are reported along with the thermodynamic simulations using Factsage. The phase diagrams of $\mathrm{SiO}_{2}-\mathrm{FeO}-\mathrm{CaO}$ [15], $\mathrm{SiO}_{2}-\mathrm{FeO}-\mathrm{TiO}_{2}$ [18], and $\mathrm{SiO}_{2}-\mathrm{CaO}-\mathrm{MgO}-\mathrm{Al}_{2} \mathrm{O}_{3}-\mathrm{FeO}-$ $\mathrm{TiO}_{2}$ [23] were calculated. The effect of $\mathrm{Cr}_{2} \mathrm{O}_{3}$ content on the amount of liquid and solid phases present in $\mathrm{CaO}-\mathrm{SiO}_{2}-\mathrm{FeO}-\mathrm{MgO}-\mathrm{MnO}-\mathrm{Cr}_{2} \mathrm{O}_{3}$ slags was reported in [19]. The solid fraction of highly basic slags was calculated in [28]. The calculated volume fraction of solid or the BOF-slags was reported in [30,31].

Chemical analysis of the slag samples after the viscosity measurements was performed only in $[17,28]$, and only Fe was analyzed in $[21,22,24]$. The non-linear relationship of the natural logarithm of viscosity with respect to inverse of the temperature from the data was reported in $[23,33]$. It is important to mention that the results of the continuous viscosity measurements were reported only in $[23,32]$.

Recently marketed and currently developed lightweight steels, which can feature TRIP/TWIP (Transformation Induced Plasticity/Twinning Induced Plasticity) effects and possessing stainless properties, often contain more than $20 \%$ of Mn along with up to $10 \%$ of $\mathrm{Al}[34,35]$. These steels are gaining a growing market share in the field of construction and automotive industries. However, considering the enrichment of $\mathrm{MnO}, \mathrm{Al}_{2} \mathrm{O}_{3}$, and $\mathrm{TiO}_{2}$ in the slag owing the recycling of modern steels in $\mathrm{BOF}$ converters or electric arc furnaces, it will lead to a considerable change in the chemical compositions of the converter slag and thus a change in their properties, which is not much explored in the presently available literature.

In present work, the flow behavior and the viscosity of the heterogeneous highly basic BOF slag are being examined considering the effect of temperature, $\mathrm{MgO}, \mathrm{Al}_{2} \mathrm{O}_{3}, \mathrm{TiO}_{2}$, and $\mathrm{MnO}$ content. Thereby, the industrial slag from an integrated steel plan was taken as the base of all the slag mixtures. The flow behavior of the slags was investigated using the high-temperature microscope. The viscosity of slags during $10{ }^{\circ} \mathrm{C} / \mathrm{min}$ cooling was continuously measured using the rotating bob rheometer. Experimental investigations were accompanied with the thermodynamic simulation using FactSage 7.2. Thereby, the solid fraction of the investigated slags and liquidus temperatures was also calculated.

\section{Materials and Methods}

An industrial BOF slag from an integrated steel plant was used to investigate the viscosity of the BOF slag. This slag was taken as the basis slag and was designated as P1. The slag was ground up and mixed with the aim of achieving the homogenization of chemical composition (see Table 1). Thereby, the chemical composition analysis was converted to $\mathrm{FeO}$. The basicity of this slag is about $4.2\left(\mathrm{CaO} / \mathrm{SiO}_{2}\right)$. In order to investigate the influence of $\mathrm{MgO}, \mathrm{MnO}, \mathrm{Al}_{2} \mathrm{O}_{3}$, and $\mathrm{TiO}_{2}$ content on the viscosity of $\mathrm{BOF}$ slag, the respective pure oxides were added into the industrial slag P1 and were ground and mixed again, as shown in Table 2. The selected oxide additives do not cover all possible chemical compositions of the slag in the case of perspective scrap from TRIP/TWIP steels, which are and will be, in fact, country-and factory-specific; however, they correlate with the average scrap and lime rates typical to that of the BOF process.

Table 1. Chemical analysis of investigated industrial slag [mass $\%]$.

\begin{tabular}{cccccccccc}
\hline Slag & $\mathrm{CaO}$ & $\mathrm{SiO}_{2}$ & $\mathbf{F e O}$ & $\mathbf{M g O}$ & $\mathrm{Al}_{2} \mathrm{O}_{3}$ & $\mathbf{M n O}$ & $\mathrm{Cr}_{2} \mathrm{O}_{3}$ & $\mathbf{P}_{2} \mathrm{O}_{5}$ & $\mathrm{TiO}_{\mathbf{2}}$ \\
\hline $\mathrm{P} 1$ & 52.16 & 12.39 & 24.64 & 2.08 & 2.10 & 3.23 & 0.36 & 2.21 & 0.83 \\
\hline
\end{tabular}


Table 2. Investigated basic oxygen furnace (BOF) slag and calculated liquidus temperature $\left[{ }^{\circ} \mathrm{C}\right]$.

\begin{tabular}{|c|c|c|}
\hline Slag & Addition & Liquidus Temperature \\
\hline P1 & P1 & 1771.3 \\
\hline P11 & $\mathrm{P} 1+3$ mass $\% \mathrm{Al}_{2} \mathrm{O}_{3}$ & 1655.4 \\
\hline P12 & $\mathrm{P} 1+9.3$ mass $\% \mathrm{Al}_{2} \mathrm{O}_{3}$ & 1274.2 \\
\hline P13 & $\mathrm{P} 1+0.4$ mass $\% \mathrm{TiO}_{2}$ & 1757.9 \\
\hline P14 & $\mathrm{P} 1+1.8$ mass $\% \mathrm{TiO}_{2}$ & 1709.8 \\
\hline P15 & $\mathrm{P} 1+5$ mass $\% \mathrm{TiO}_{2}$ & 1589.5 \\
\hline P16 & $\mathrm{P} 1+1$ mass $\% \mathrm{MnO}$ & 1779.0 \\
\hline P17 & $\mathrm{P} 1+7$ mass $\% \mathrm{MnO}$ & 1813.0 \\
\hline P2 & $\mathrm{P} 1+6.5$ mass $\% \mathrm{MgO}$ & 1864.8 \\
\hline P21 & $\mathrm{P} 1+6.5$ mass $\% \mathrm{MgO}+3$ mass $\% \mathrm{Al}_{2} \mathrm{O}_{3}$ & 1832.3 \\
\hline $\mathrm{P} 22$ & $\mathrm{P} 1+6.5$ mass $\% \mathrm{MgO}+8$ mass $\% \mathrm{Al}_{2} \mathrm{O}_{3}$ & 1768.1 \\
\hline $\mathrm{P} 23$ & $\mathrm{P} 1+6.5$ mass $\% \mathrm{MgO}+1$ mass $\% \mathrm{TiO}_{2}$ & 1853.0 \\
\hline $\mathrm{P} 24$ & $\mathrm{P} 1+6.5$ mass $\% \mathrm{MgO}+5$ mass $\% \mathrm{TiO}_{2}$ & 1834.1 \\
\hline P25 & $\mathrm{P} 1+6.5$ mass $\% \mathrm{MgO}+1.9$ mass $\% \mathrm{MnO}$ & 1856.5 \\
\hline P26 & $\mathrm{P} 1+6.5$ mass $\% \mathrm{MgO}+6.8$ mass $\% \mathrm{MnO}$ & 1852.1 \\
\hline
\end{tabular}

In order to assure the target liquid surface level between 30 and $35 \mathrm{~mm}$ in the molybdenum crucible (inner diameter $20 \mathrm{~mm}$, and inner height $60 \mathrm{~mm}$ ), the mixtures were premelted under the Ar-gas atmosphere before the viscosity measurements. The chemical analysis of the slag samples was carried out before and after the viscosity measurements using a X-ray fluorescence spectrometer Bruker AXS S8 Tiger (XRF) (Bruker AXS GmbH, Karlsruhe, Germany). The basicity of the slags remained unchanged at 4.2. The liquidus temperature of investigated slag samples was calculated using FactSage7.2 (FactPS, FTOxid, all "Base-Phase") (Thermfact/CRCT Montreal, Canada and GTT-Technologies, Aachen, Germany).

The slag was mixed uniformly and compacted into cylindrical samples of $5 \mathrm{~mm}$ diameter and $5 \mathrm{~mm}$ height for the investigation of melting behavior in the high-temperature microscope. The high-temperature microscope detailed description and experimental procedure can be found elsewhere [36]. The experiments were carried out under argon atmosphere. The softening, semi-spherical, and flow temperatures of the slags were defined according to the German standard DIN $51730[37,38]$. Some studies in the past have assumed that the flow temperature is the melting or liquidus temperature of the slags [37], by which the solid slag has been completely melted to the liquid state, which is not the case. Flow temperature is considered as the temperature at which even the heterogeneous slag begins to flow.

The experimental procedure of the viscosity measurements used in the present work is the same as that described in the previous works reported in $[39,40]$. The sample was heated in the induction furnace via indirect heating using the graphite susceptor to the target temperature at a rate of $18-20^{\circ} \mathrm{C}$ per minute in order to prevent the boiling of the slag. Then, it was kept for at least $30 \mathrm{~min}$ at this temperature to achieve homogenization of the sample. The procedure of the slag surface level estimation is executed during the holding time: slow immersion of the rotating bob into the crucible with simultaneously recording the torque using the magnet head of the rheometer MCR 301 (Anton Paar GmbH, Graz, Austria). After attaining the contact with the liquid slag surface, the necessary immersion depth of the rotating bob was calculated, and it was placed at the target height. The viscosity of the sample is measured in the cooling mode at the rate of $10 \mathrm{~K} / \mathrm{min}$ until the solidification of the sample has started. The bob was rotated at $30 \mathrm{rpm}$. All these procedures of heating, holding for $30 \mathrm{~min}$, and subsequent cooling are repeated 3 times. The inner volume of the furnace is flushed with argon during the experiment in order to keep the oxidation of the crucible, the bob, and the sample to the minimum possible extent. Temperature is controlled using the arrangement of two B-Type thermocouples attached to the bottom and the top of the Mo crucible. 


\section{Results and Discussion}

\subsection{Liquidus Temperature and Melting Behavior}

Table 3 shows the measured softening, semi-spherical, and flow temperatures of the BOF slags using a high-temperature microscope according to DIN 51730 [38]. The calculated liquidus temperature, as shown in Table 2, and the three measured temperatures increase with the addition of $\mathrm{MgO}$. The additions of $\mathrm{Al}_{2} \mathrm{O}_{3}$ between 3 and 9 mass\% significantly lowers the characteristic temperatures of the investigated slags. That means that the characteristic temperatures decrease approximately linearly with the amount of $\mathrm{Al}_{2} \mathrm{O}_{3}$. At the same time, the $\mathrm{Al}_{2} \mathrm{O}_{3}$ reduces the liquidus temperature and melting temperatures of the slag with 2 mass \% of $\mathrm{MgO}$ more effectively than for the slag with 8 mass $\%$ of $\mathrm{MgO}$. The additions of $\mathrm{TiO}_{2}$ between 1 and 5 mass $\%$ decrease the characteristic temperatures of the slag with 8 mass $\%$ of $\mathrm{MgO}$, implying that the influence of $\mathrm{TiO}_{2}$ is weaker than that of $\mathrm{Al}_{2} \mathrm{O}_{3}$. The characteristic temperatures of the slag with 2 mass $\%$ of $\mathrm{MgO}$ decreases with additions of $\mathrm{TiO}_{2}$ up to approximately 2 mass $\%$, and they increase again with the further additions. A possible cause can be the formation of $3 \mathrm{CaO}^{*} 2 \mathrm{TiO}_{2}$, which is also confirmed by the calculation of a solid fraction using FactSage 7.2. The melting behavior of MnO-containing slag with 2 mass $\%$ of $\mathrm{MgO}$ shows that addition of $1 \%$ more $\mathrm{MnO}$ led to higher characteristic temperatures of the sample, while the addition of $7 \% \mathrm{MnO}$ did not show a significant further increase. In the case of slag with $8 \mathrm{mass} \% \mathrm{of} \mathrm{MgO}$, the characteristic temperatures first rose at $2 \%$ additional $\mathrm{MnO}$, while significantly decreased when $7 \%$ of $\mathrm{MnO}$ was added.

Table 3. Measured softening, semi-spherical, and flow temperatures of the BOF slags.

\begin{tabular}{|c|c|c|c|c|c|c|}
\hline Slag & \multicolumn{2}{|c|}{ Softening Temperature $\left[{ }^{\circ} \mathrm{C}\right]$} & \multicolumn{2}{|c|}{ Hemispherical Temperature $\left[{ }^{\circ} \mathrm{C}\right]$} & \multicolumn{2}{|c|}{ Flow Point Temperature $\left[{ }^{\circ} \mathrm{C}\right]$} \\
\hline P11 & 1177 & 8.89 & 1268 & 4.16 & 1311 & 1.53 \\
\hline P12 & 1068 & 13.20 & 1094 & 13.58 & 1145 & 19.70 \\
\hline P15 & 1214 & 5.13 & 1248 & 4.16 & 1282 & 11.14 \\
\hline P16 & 1353 & 14.14 & 1398 & 21.22 & 1408 & 7.07 \\
\hline P17 & 1381 & 4.95 & 1405 & 12.02 & 1418 & 13.43 \\
\hline P2 & 1414 & 6.70 & 1473 & 8.20 & 1489 & 7.6 \\
\hline P21 & 1371 & 16.20 & 1419 & 7.00 & 1438 & 4.40 \\
\hline P26 & 1407 & 4.94 & 1441 & 4.95 & 1453 & 4.94 \\
\hline
\end{tabular}

Another influence of $\mathrm{TiO}_{2}$ and $\mathrm{Al}_{2} \mathrm{O}_{3}$ on the $\mathrm{BF}$ slag is known from the literature. Jiao et al. [13] reported that the liquidus temperature of $\mathrm{BF}$ slag decreases first with an increase of $\mathrm{Al}_{2} \mathrm{O}_{3}$ up to $12-14 \mathrm{wt} \%$ of $\mathrm{Al}_{2} \mathrm{O}_{3}$, reaches a minimum, and then continues to increase with the further increase in $\mathrm{Al}_{2} \mathrm{O}_{3}$ content higher than 12-14 wt\%. The optimum value of $\mathrm{Al}_{2} \mathrm{O}_{3}$ content depends on the $\mathrm{MgO}, \mathrm{FeO}$, and basicity [13]. The influence of $\mathrm{TiO}_{2}$ content between 5 and $15 \mathrm{wt} \%$ on the melting behavior and viscosity of the BF slags was investigated by Zhang et al. using the high-temperature microscope [23]. It was estimated that the initial melting point temperature, softening temperature, and flowing temperature of $\mathrm{BF}$ slag increases with any increase in the $\mathrm{TiO}_{2}$ content.

\subsection{Fraction of Solid}

The calculated liquidus temperature showed that the most investigated BOF slags are heterogeneous at the examined temperature ranges. Therefore, the solid fraction was calculated using 
the FactSage7.2 database FactPS and FTOxid (all "Base-Phase"), as shown in Figure 1. The undissolved solid solution of $\mathrm{CaO}$ in the slag with 2 mass $\% \mathrm{MgO}$, and undissolved solid solutions of $\mathrm{CaO}$ and $\mathrm{MgO}$ in slag samples with 8 mass\% $\mathrm{MgO}$, were found in the investigated temperature range. The solid fractions of the slags $\mathrm{P} 1$ and $\mathrm{P} 2$ at the temperature of $1700{ }^{\circ} \mathrm{C}$ are 3 and 9 mass $\%$, respectively. In all the slags without additional $\mathrm{Al}_{2} \mathrm{O}_{3}$, at temperatures below $1450{ }^{\circ} \mathrm{C}$, the $2 \mathrm{CaO}^{*} \mathrm{SiO}_{2}$ phase was formed. Moreover, with the addition of $\mathrm{MnO}$, the amount of this $2 \mathrm{CaO}^{*} \mathrm{SiO}_{2}$ phase in the slag with 8 mass $\% \mathrm{MgO}$ increases. Calculations with FactSage showed that the addition of $\mathrm{Al}_{2} \mathrm{O}_{3}$ prevents the formation of the $2 \mathrm{CaO}^{*} \mathrm{SiO}_{2}$ phase in the studied slags $\mathrm{P} 11$ and $\mathrm{P} 12$. The $\mathrm{TiO}_{2}$ additions lead to the formation of $3 \mathrm{CaO}^{*} 2 \mathrm{TiO}_{2}$ at temperatures below $1450{ }^{\circ} \mathrm{C}$. The fraction of solids gradually rises as the temperature decreases.

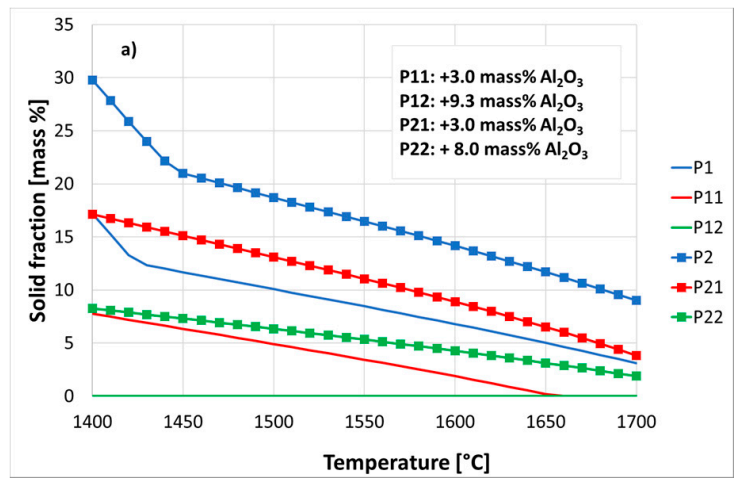

(a)

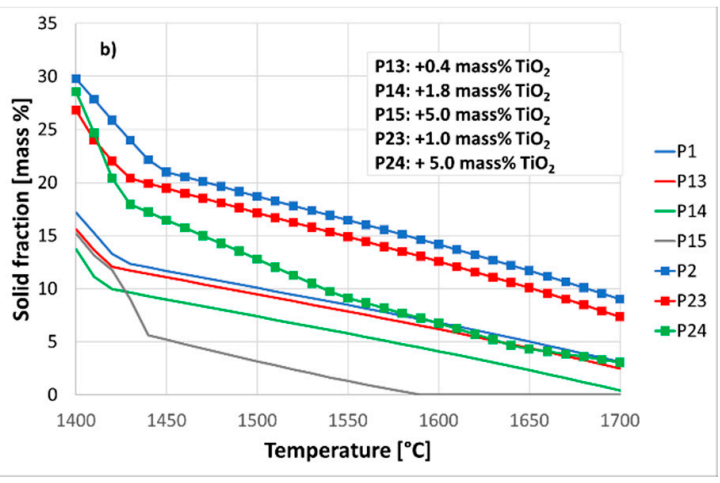

(b)

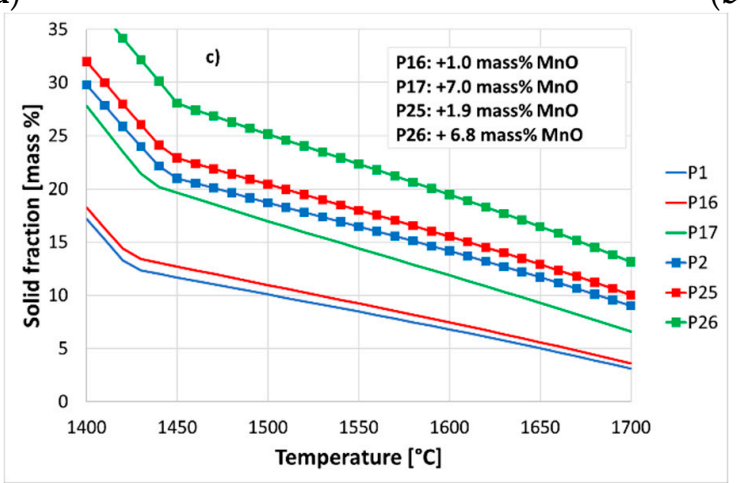

(c)

Figure 1. Solid fraction with respect to temperature for the addition of (a) $\mathrm{Al}_{2} \mathrm{O}_{3}$ (b) $\mathrm{TiO}_{2}$, and (c) $\mathrm{MnO}$.

According to FactSage calculations, the addition of $\mathrm{MnO}$ raises the amount of solid fraction in all the investigated slags, as shown in Figure 1c. From the literature [41], it is known that $\mathrm{MnO}$ with its contents below 20 mass \% does not affect the dissolution and saturation of $\mathrm{CaO}$.

The volume fraction of solid was reported to be calculated using FactSage for the industrial BOF slag containing 2.37-2.41 wt\% of $\mathrm{MgO}$, and levels of $\mathrm{P}_{2} \mathrm{O}_{5}, \mathrm{MnO}, \mathrm{V}_{2} \mathrm{O}_{3}, \mathrm{Cr}_{2} \mathrm{O}_{3}$, and $\mathrm{TiO}_{2}$ typical for the BOF process. Even at the temperature of $1700{ }^{\circ} \mathrm{C}$, this slag had approximately $8.5 \%$ of the volume fraction of solid [30]. The volume fraction of solid in a BOF slag as a function of added $\mathrm{SiO}_{2}$ and $\mathrm{Al}_{2} \mathrm{O}_{3}$ is also reported as calculated using FactSage. According to the calculation, solid $\mathrm{CaO}$ was present in the investigated slags in the temperature range from 1550 to $1700{ }^{\circ} \mathrm{C}$. It was found that $\mathrm{Al}_{2} \mathrm{O}_{3}$ and $\mathrm{SiO}_{2}$ lead to a decrease in the fraction of solid phases [31]. The mass fraction of solid was reported as calculated using FactSage for synthetic highly basic $\mathrm{CaO}-\mathrm{SiO}_{2}-\mathrm{FeO}-\mathrm{MgO}$ and $\mathrm{CaO}-\mathrm{SiO}_{2}-\mathrm{FeO}-\mathrm{Al}_{2} \mathrm{O}_{3}-\mathrm{MgO}$ slags. The solid phases found in these compositions were $2 \mathrm{CaO}^{*} \mathrm{SiO}_{2}$ and $(\mathrm{Mg}, \mathrm{Fe}) \mathrm{O}_{\text {solid solutions [28]. }}$. 


\subsection{Viscosity}

\subsubsection{Comparison with Literature Data}

Figure 2 shows the continuously measured viscosity of BOF slags P1 and P2 as a function of temperature. The measured values were compared with previous studies $[28,29,31]$. The measured viscosities are in the same range as the viscosities from the literature.

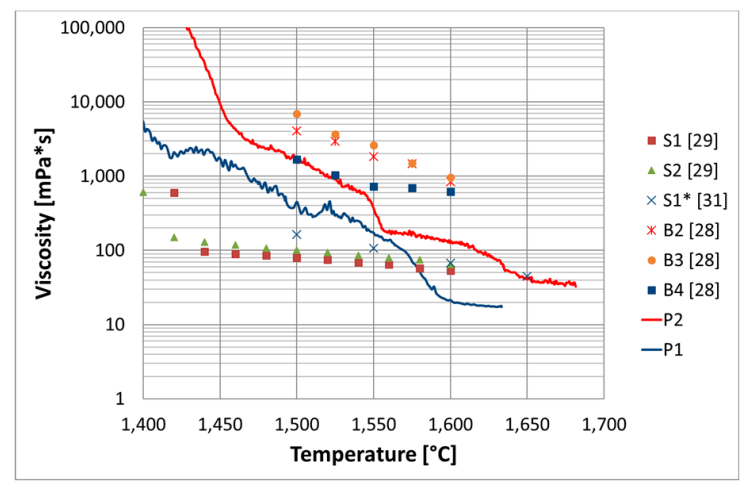

Figure 2. Comparison of measured viscosity with literature values from $[28,29,31]$.

The investigated slags do not have exactly the same chemical composition as examples reported in the literature (see Table 4). The slags differ mainly in basicity, $\left(\mathrm{CaO} / \mathrm{SiO}_{2}\right.$ ratio). If the slags $\mathrm{B} 2-\mathrm{B} 4$ from [28] have a basicity of approximately 6, the basicity of the slags S1 and S2 from [29] is near 3, and their $\mathrm{MgO}$ content is equal to 5 mass\%. The $\mathrm{S1}^{*}$ slag from [31] has a basicity between 3 and 3.5 . Both the slags investigated in this work, $\mathrm{P} 1$ and $\mathrm{P} 2$, had a $\mathrm{CaO} / \mathrm{SiO}_{2}$ ratio that is equal to 4.2. The P1 and P2 samples differ in $\mathrm{MgO}$ content as well, which is approximately 2 and 8 mass \% respectively. Increasing the $\mathrm{MgO}$ content in the slag leads to the growth of the solid fraction volume and as a result increases the viscosity.

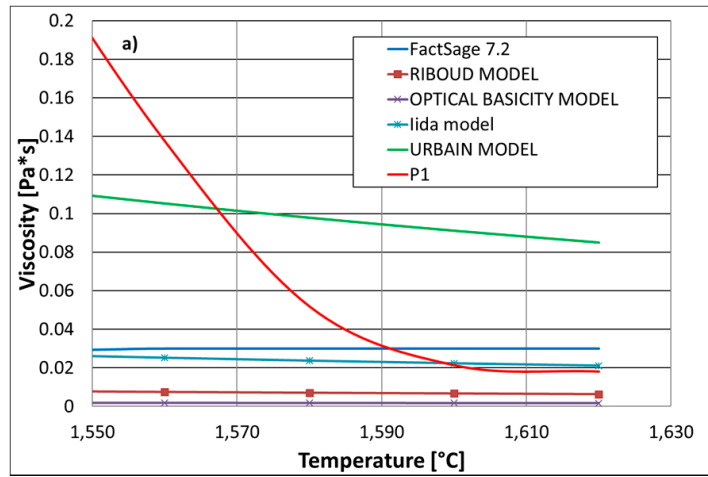

(a)

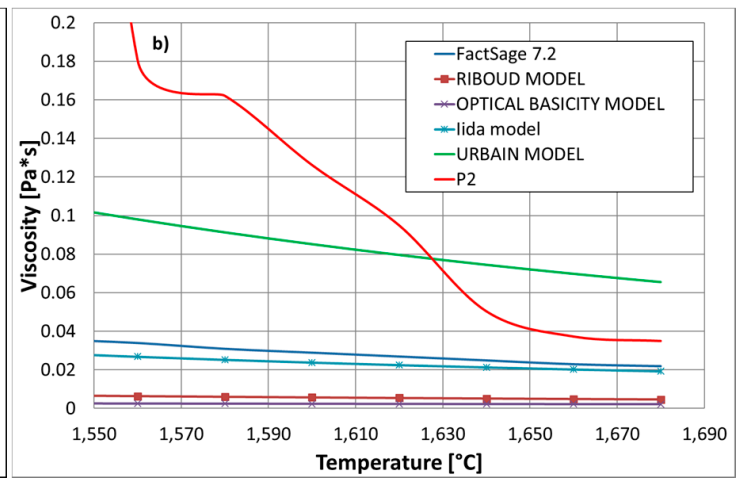

(b)

Figure 3. Comparison of the calculated viscosity by various models and the measured viscosity of slags P1 (a) and P2 (b).

The high basic slags B2-B4 [28] were investigated using a rotating viscosimeter in Pt-12 mass\% $\mathrm{Rh}$ crucible and with three different rotating speeds (30,60, and $100 \mathrm{rpm})$. The chemical analysis of slag samples was performed after the viscosity measurement using an X-ray fluorescence spectrometer. Thereby no significant changes in the composition were observed. The viscosity of slags S1-S2 [29] and $S 1^{*}$ [31] were measured using the rotating cylinder method. The experiments were carried out in a molybdenum crucible under the argon atmosphere with a constant rotating speed of about $200 \mathrm{rpm}[29,31]$. The rotation speed of about $30 \mathrm{rpm}$ was set, in the present work, to avoid the vortex formation in a $4 \mathrm{~mm}$ gap between the bob and the molybdenum crucible. 
Table 4. Chemical composition (in mass\%) of the reference slags from Figure 3.

\begin{tabular}{cccccc}
\hline [Ref] & $\mathbf{C a O}$ & $\mathbf{S i O}_{\mathbf{2}}$ & $\mathbf{F e O}$ & $\mathbf{A l}_{\mathbf{2}} \mathbf{O}_{\mathbf{3}}$ & $\mathbf{M g O}$ \\
\hline $\mathrm{B} 2[28]$ & 46.4 & 7.8 & 30.0 & 3.5 & 7.8 \\
$\mathrm{~B} 3[28]$ & 49.9 & 8.3 & 25.0 & 3.7 & 8.3 \\
$\mathrm{~B} 4[28]$ & 53.1 & 8.9 & 20.0 & 4.0 & 8.9 \\
$\mathrm{~S} 1[29]$ & 48.75 & 16.25 & 25 & 5 & 5 \\
$\mathrm{~S} 2[29]$ & 48.75 & 16.25 & 20 & 10 & 5 \\
$\mathrm{~S}^{*}[31]$ & $42-55$ & $12-18$ & $14-20$ (Fet) & $0.0-3.0$ & $0.0-5.0$ \\
\hline
\end{tabular}

The chemical analysis of the investigated slags in the present work was carried out also after the viscosity measurements. Unfortunately, strong contamination with molybdenum (10-14 mass\% $\mathrm{Mo}_{\text {met }}$ ) from the crucible was also observed. As already mentioned in the Introduction section, the chemical analyses after the viscosity measurements were checked and reported only in very rare studies. Thereby, no change or no contamination or minor contamination was previously reported. It was found that the molybdenum from the crucible was dissolved in the slags during viscosity measurements of FeO-containing nickel slag $\left(\mathrm{MoO}_{3}\right.$ concentrations of $0.25-0.52 \mathrm{wt} \%$ and $0.25-0.46 \mathrm{wt} \%$ for higher and lower FeO content, respectively) [21,22]. The viscosity curves in our experiments were repeated several times. The data only from the fresh slags and new crucible were used for reporting in the present work.

Viscosities of slags P1 and P2 were calculated using the FactSage 7.2, using models Lida [42], Urbain [43], Riboud [44], and an optical basicity model [8]. A comparison of measured and calculated viscosities is presented in Figure 3. It can be seen from the comparison that at higher temperatures, the measured viscosity of slag P1 matches the calculated viscosity with the Lida model. In the case of slag P2, the measured viscosity overrides calculations with the Lida model and FactSage 7.2. The models fail when the temperature drops and the solid phase nucleates in the slag. In general, the calculated viscosity from models is always less than the experimentally measured viscosity.

\subsubsection{Influence of $\mathrm{Al}_{2} \mathrm{O}_{3}$}

Figure 4 shows the viscosity of $\mathrm{BOF}$ slags at variable $\mathrm{Al}_{2} \mathrm{O}_{3}$ content. In slags with approximately 2 mass $\%$ of $\mathrm{MgO}, \mathrm{Al}_{2} \mathrm{O}_{3}$ increases the viscosity at high temperatures, in the region of liquid-determined slag, and decreases the viscosity at low temperatures. A similar result was also reported by Liu et al. for the slag with $0-5$ mass $\% \mathrm{MgO}$. They found that $\mathrm{Al}_{2} \mathrm{O}_{3}$ and $\mathrm{SiO}_{2}$ reduce the viscosity of $\mathrm{BOF}$ slags as long as they lead to a decrease in the fraction of the solid phases, but they raise the viscosity of the liquid slag by network forming [31].

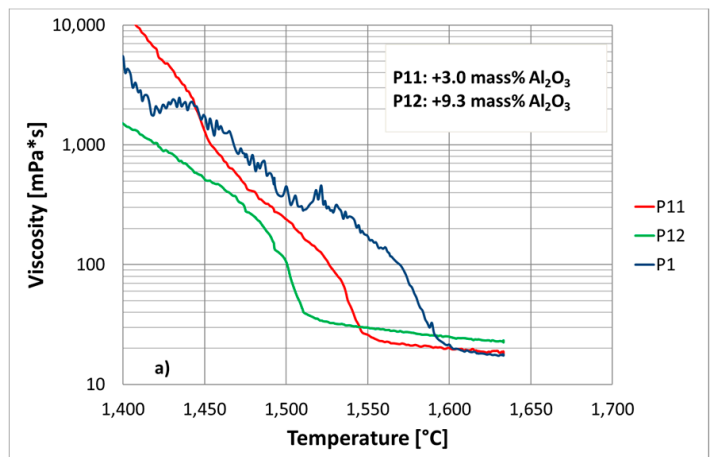

(a)

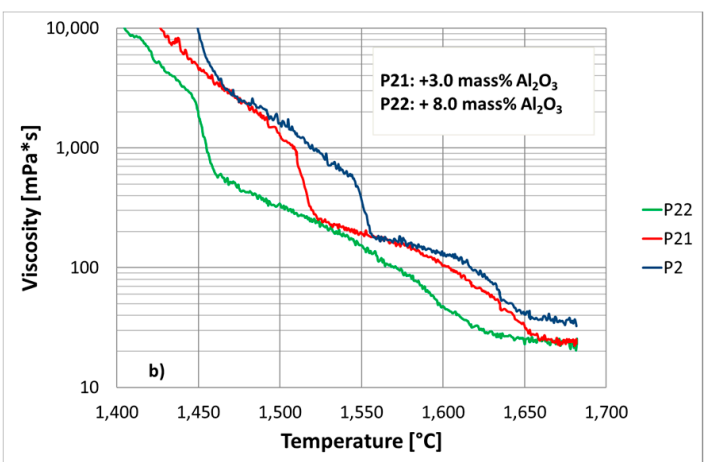

(b)

Figure 4. Viscosity of the BOF slag with 2 (a) and 8 mass $\%$ of $\mathrm{MgO}(\mathbf{b})$ as a function of temperature for various $\mathrm{Al}_{2} \mathrm{O}_{3}$ contents.

In slags with approximately 8 mass $\%$ of $\mathrm{MgO}(\mathrm{P} 2-\mathrm{P} 22), \mathrm{Al}_{2} \mathrm{O}_{3}$ reduces the viscosity across the entire studied temperature range. In the temperatures above $1650{ }^{\circ} \mathrm{C}$, the viscosity of the slag with the 
addition of 3 mass $\% \mathrm{Al}_{2} \mathrm{O}_{3}$ (P21) is the same as that of the slag with the addition of 8 mass $\% \mathrm{Al}_{2} \mathrm{O}_{3}$ (P22). These results are similar to the results reported by Seok et al. [28].

They also found that the $\mathrm{Al}_{2} \mathrm{O}_{3}$ content affected the viscosity of the highly basic slag with about 8-9 mass\% MgO more strongly than the MgO content. Furthermore, the slag viscosity exhibits different behavior with the decreasing temperature, whereas there is no significant difference in the viscosity values for the temperatures above $1500^{\circ} \mathrm{C}$.

\subsubsection{Influence of $\mathrm{TiO}_{2}$}

Figure 5 shows the viscosity of $\mathrm{BOF}$ slags as a function of $\mathrm{TiO}_{2}$. In slags derived from $\mathrm{P} 1$, viscosity at higher temperatures above $1600^{\circ} \mathrm{C}$ does not depend on the $\mathrm{TiO}_{2}$ content. Furthermore, with a decrease in the temperature, the addition of $\mathrm{TiO}_{2}$ first reduces and then increases the viscosity. At higher temperatures above $1650{ }^{\circ} \mathrm{C}$, the addition of $\mathrm{TiO}_{2}$ to the slags derived from $\mathrm{P} 2$ shows the decrease in the viscosity. Then, with the decreasing temperature, the viscosity increases with the addition of $\mathrm{TiO}_{2}$.

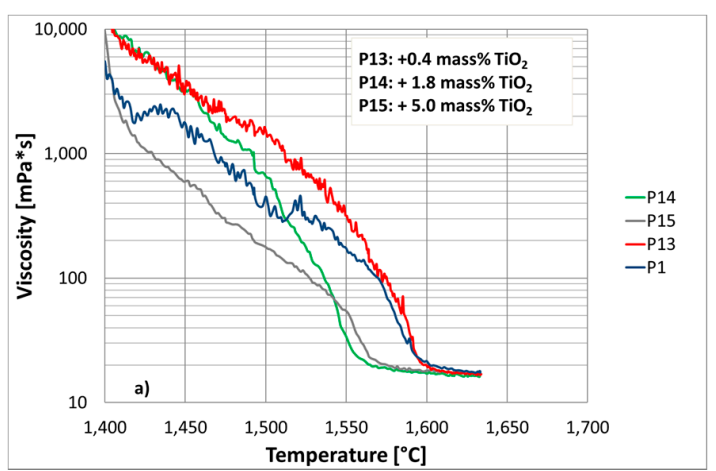

(a)

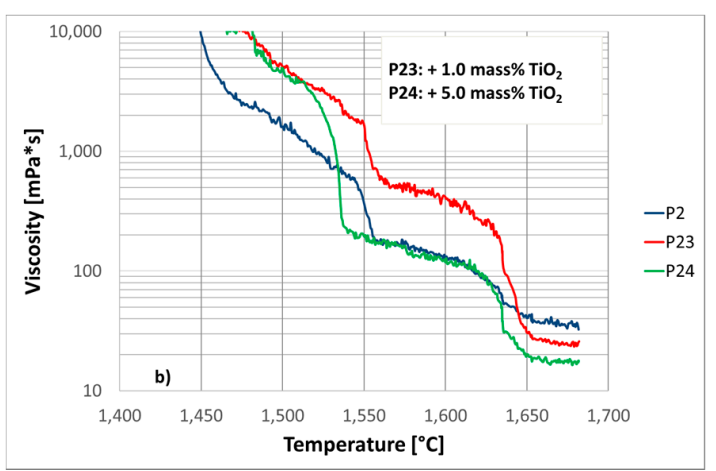

(b)

Figure 5. Viscosity of the BOF slag with 2 (a) and 8 mass $\%$ of $\mathrm{MgO}(\mathbf{b})$ as function of $\mathrm{TiO}_{2}$ content.

There is no information about the influence of $\mathrm{TiO}_{2}$ on the viscosity of $\mathrm{BOF}$ slag available in the literature. It is known from the investigation of viscosity of BF slag that the viscosity of blast furnace (BF) slags decreases with the increasing $\mathrm{TiO}_{2}$ content between 5 and $15 \mathrm{wt} \%$ in the higher temperature range and concomitantly increases in the relative lower temperature range [23]. It was found that the viscosity of the $\mathrm{BF}$ slag decreases rapidly with the increasing of $\mathrm{TiO}_{2}$ up to $10 \%$; then, it decreases slowly, when the $\mathrm{TiO}_{2}$ content increases above 10\% [24]. Raman spectroscopy and FTIR spectroscopy of these $\mathrm{BF}$ slags in cold state implied that the degree of polymerization of $\mathrm{BF}$ slag decreases with increasing $\mathrm{TiO}_{2}$. Li et al. reported that the viscosity of the $\mathrm{BF}$ slag containing 10 mass $\% \mathrm{TiO}_{2}$ first increases and then decreases with increasing $\mathrm{Al}_{2} \mathrm{O}_{3}$ content from 10 to 18 mass\%, exhibiting the maximum viscosity at $15 \% \mathrm{Al}_{2} \mathrm{O}_{3}$, while an increase in $\mathrm{TiO}_{2}$ content from 2 to 14 mass $\%$ causes a decrease in the viscosity of the slag at 12 mass $\% \mathrm{Al}_{2} \mathrm{O}_{3}$ [25].

\subsubsection{Influence of $\mathrm{MnO}$}

Figure 6 shows the viscosity of BOF slags as a function of $\mathrm{MnO}$. At high temperatures, the viscosity of the slag with 2 mass $\% \mathrm{MgO}$ practically does not change with the addition of $\mathrm{MnO}$. Adding $\mathrm{MnO}$ to slag with 8 mass $\% \mathrm{MgO}$ reduces the viscosity at high temperatures. With decreasing temperature, the viscosity of all the studied slags increases with MnO. Calculations with FactSage 7.2 showed that with the addition of $\mathrm{MnO}$, the solid fraction in the slags increases. For example, at a temperature of $1700{ }^{\circ} \mathrm{C}$, the addition of 6.8 mass $\% \mathrm{MnO}$ to $\mathrm{P} 2$ increases the solid fraction from $9 \%$ to $13 \%$, and the addition of $7 \mathrm{mass} \%$ of $\mathrm{MnO}$ to $\mathrm{P} 1$ increases that from 3\% to $6.6 \%$. Moreover, with the addition of $\mathrm{MnO}$, the amounts of $\left(\mathrm{Ca}^{*} \mathrm{Mn}\right) \mathrm{O}$ solid solution and $\left(\mathrm{Mg}^{*} \mathrm{Mn}\right) \mathrm{O}$ solid solution increase. At the same time, the amount of $\mathrm{CaO}$ in the residual liquid slag decreases, which leads to a decrease in the $\mathrm{CaO} / \mathrm{SiO}_{2}$ ratio. For example, the ratio $\mathrm{CaO} / \mathrm{SiO}_{2}$ decreases in the residual liquid part of the slag from 4.2 to 3.5 
with an addition of 6.8 mass $\%$ in slag P26. It is possible that this decrease in basicity with the addition of $\mathrm{MnO}$ leads to a decrease in the viscosity at high temperature.

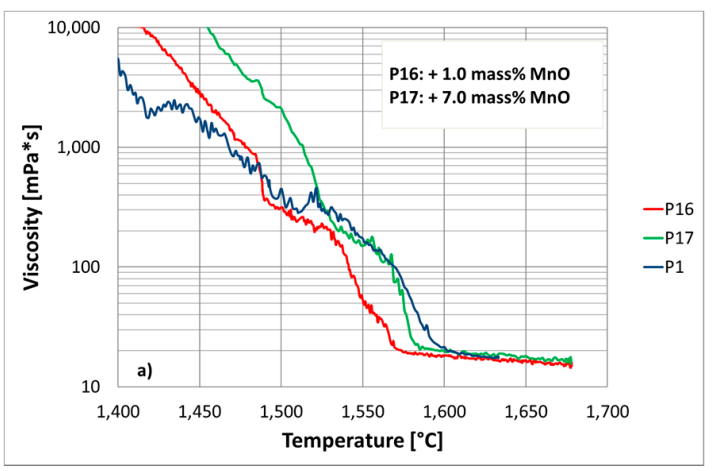

(a)

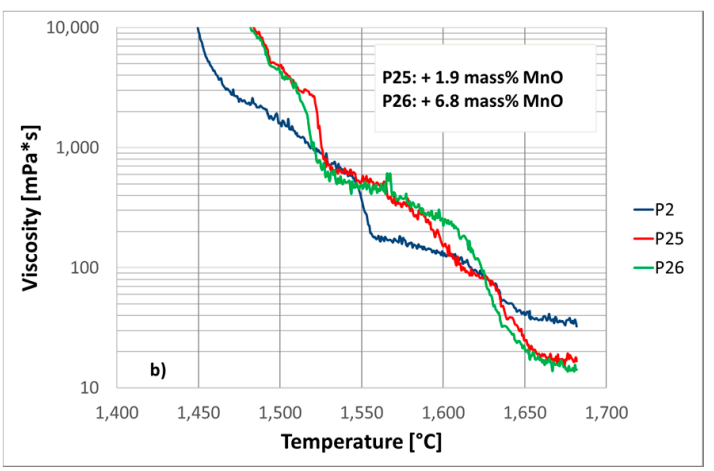

(b)

Figure 6. Viscosity of the BOF slag with 2 (a) and 8 mass $\%$ of $\mathrm{MgO}(\mathbf{b})$ as function of $\mathrm{MnO}$ content.

The measured viscosity values are presented in the Tables 5 and 6 .

Table 5. Viscosity of the BOF slags with 2 mass $\% \mathrm{MgO}\left[\mathrm{mPa}^{*} \mathrm{~s}\right]$.

\begin{tabular}{ccccccccc}
\hline$\left[{ }^{\circ} \mathbf{C}\right]$ & P1 & P11 & P12 & P13 & P14 & P15 & P16 & P17 \\
\hline 1680 & - & - & - & - & - & - & - & - \\
1660 & - & - & - & - & - & - & 15.90 & 17.39 \\
1640 & - & - & - & - & - & - & 16.91 & 18.54 \\
1620 & 18.11 & 18.86 & 23.43 & 17.29 & 16.77 & 17.48 & 17.29 & 18.79 \\
1600 & 21.40 & 20.18 & 25.01 & 19.78 & 17.15 & 18.04 & 18.21 & 19.92 \\
1580 & 51.88 & 21.30 & 26.48 & 72.76 & 18.04 & 19.07 & 18.95 & 25.50 \\
1560 & 137.59 & 22.78 & 28.70 & 217.15 & 22.26 & 29.78 & 38.22 & 138.88 \\
1540 & 248.92 & 43.54 & 30.87 & 525.41 & 84.55 & 73.07 & 123.18 & 190.50 \\
1520 & 371.40 & 131.26 & 34.72 & 812.55 & 221.51 & 118.49 & 216.46 & 581.28 \\
1500 & 446.63 & 240.82 & 105.66 & 1537.92 & 707.40 & 176.97 & 314.96 & 2104.37 \\
1480 & 744.91 & 410.77 & 255.18 & 1969.80 & 1252.98 & 269.86 & 977.81 & 3702.78 \\
1460 & 1421.06 & 812.85 & 453.24 & 2914.62 & 2134.83 & 495.85 & 2037.40 & 7856.74 \\
1440 & 2051.39 & 2815.29 & 664.58 & 3722.91 & 3844.34 & 757.85 & 4204.06 & $24,023.87$ \\
1420 & 2092.54 & 6433.04 & 1035.70 & 6060.85 & 6908.99 & 1241.39 & 8663.15 & $63,612.35$ \\
1400 & 5454.04 & $14,354.2$ & 1501.07 & $22,479.67$ & $12,848.60$ & 9337.19 & $17,406.9$ & - \\
\hline
\end{tabular}

Table 6. Viscosity of the BOF slags with 8 mass $\% \mathrm{MgO}\left[\mathrm{mPa}^{*} \mathrm{~s}\right]$.

\begin{tabular}{cccccccc}
\hline$\left[{ }^{\circ} \mathbf{C}\right]$ & P2 & P21 & P22 & P23 & P24 & P25 & P26 \\
\hline 1680 & 34.97 & 24.53 & 22.15 & 24.61 & 17.36 & 16.44 & 14.14 \\
1660 & 37.28 & 25.31 & 24.53 & 26.16 & 17.50 & 18.42 & 17.49 \\
1640 & 50.38 & 42.81 & 28.87 & 77.19 & 27.97 & 38.08 & 30.64 \\
1620 & 94.93 & 32.75 & 32.69 & 217.16 & 99.79 & 86.88 & 117.77 \\
1600 & 126.24 & 103.25 & 47.47 & 410.80 & 119.31 & 150.78 & 229.82 \\
1580 & 162.15 & 150.65 & 85.12 & 486.79 & 134.88 & 300.56 & 326.98 \\
1560 & 180.72 & 180.91 & 116.24 & 592.84 & 173.64 & 504.71 & 457.11 \\
1540 & 619.96 & 210.26 & 183.24 & 2022.99 & 214.18 & 652.45 & 516.18 \\
1520 & 1016.03 & 300.65 & 244.51 & 3291.47 & 2798.07 & 2691.47 & 1041.17 \\
1500 & 1611.11 & 1271.62 & 340.40 & 5061.73 & 4941.33 & 4833.83 & 4252.74 \\
1480 & 2334.75 & 2312.21 & 427.76 & 8952.59 & $10,729.79$ & $11,418.18$ & $10,816.13$ \\
1460 & 4306.95 & 3396.27 & 622.88 & $16,528.3$ & $43,442.46$ & $29,928.67$ & $25,263.53$ \\
1440 & $32,726.2$ & 6313.13 & 3260.40 & $151,652.1$ & - & $67,758.63$ & $46,999.61$ \\
1420 & - & $13,361.71$ & 6526.99 & - & - & - & - \\
1400 & - & - & $12,648.05$ & - & - & - & - \\
\hline
\end{tabular}




\subsection{Activation Energy}

All the measured slag viscosity was presented as a natural logarithm of the viscosity with respect to the inverse of temperature in Kelvin (1/T) (Arrhenius plot) to determine the activation energy of the studied slags. Figure 7 shows an example of this kind of plot. The Arrhenius plot shows that there are four periods of different behaviors, namely: slow period (I.), rapid period (II.), slow-down period (III.) and dramatically rising period (IV.). A similar change in the natural logarithm of the viscosity with respect to the inverse of temperature was presented in the available literature $[23,33]$. In period I., most of the investigated slags are heterogeneous, but nevertheless, this period can be defined as liquid-dominated. Rapid increases of the viscosity values with the decreasing temperature in periods II. and IV. are believed to be directly related to the crystallization of the slag.

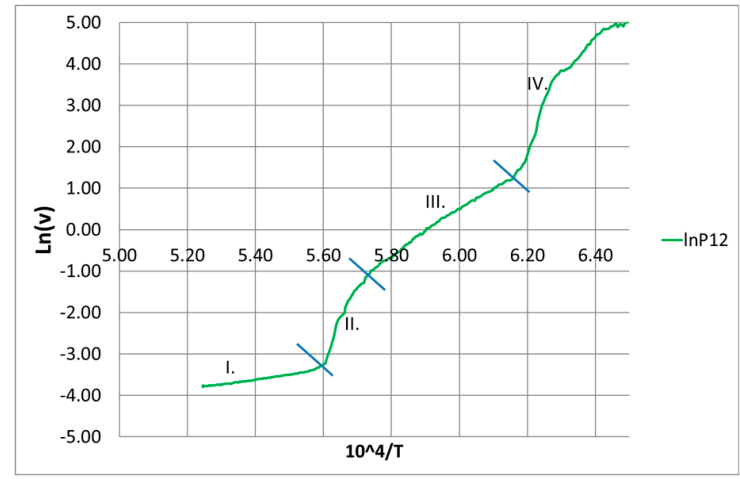

Figure 7. Arrhenius plot of viscosity of slag P12.

The activation energy for the studied slags was determined as a slope of the curve only for the liquid-dominated period I. (Tables 7 and 8). The activation energies of investigated BOF slags were determined to be 8 to $44 \mathrm{~kJ} / \mathrm{mol}$ for the composition range investigated, and they increase with the increasing $\mathrm{MgO}$ concentration and decrease with the increase in $\mathrm{Al}_{2} \mathrm{O}_{3}, \mathrm{TiO}_{2}$, and $\mathrm{MnO}$ content.

Table 7. Activation energies for the BOF slags with $2 \% \mathrm{MgO}[\mathrm{kJ} / \mathrm{mol}]$.

\begin{tabular}{cccccccc}
\hline P1 & P11 & P12 & P13 & P14 & P15 & P16 & P17 \\
\hline 22.87 & 9.86 & 9.53 & 14.82 & 10.29 & 9.34 & 8.20 & 10.44 \\
\hline
\end{tabular}

Table 8. Activation energies for the BOF slags with $8 \% \mathrm{MgO}[\mathrm{kJ} / \mathrm{mol}]$.

\begin{tabular}{ccccccc}
\hline P2 & P21 & P22 & P23 & P24 & P25 & P26 \\
\hline 43.31 & 33.42 & 10.07 & 31.66 & 16.67 & 34.05 & 38.82 \\
\hline
\end{tabular}

The obtained activation energies of BOF slags are lower compared to the activation energies of BF slag reported in the literature (70.6 and $140.4 \mathrm{~kJ} / \mathrm{mol}$ in [25] and approximately 75-140 kJ/mol in [23]). The activation energy of slag compositions close to that of BOF slag was reported to be between 4 and $29 \mathrm{~kJ} / \mathrm{mol}[29]$.

\subsection{Industrial Significance}

The viscosity of the slag plays a crucial role during industrial steelmaking operation because it determines the fluidity of the slag and effectiveness of the mass transfer, which further controls slag-metal reactions. During the BOF steelmaking, phosphorous transfer from slag to metal is one of the reactions in the slag phase, which is controlled by mass transfer. If we can understand the effect of various constituents present in the slag phase on the viscosity, it would definitely help to control the industrial BOF steelmaking process in an effective manner. 


\section{Conclusions}

The viscosities of the representative $\mathrm{BOF}$ slags with varying compositions of $\mathrm{MgO}, \mathrm{Al}_{2} \mathrm{O}_{3}, \mathrm{TiO}_{2}$ ， and $\mathrm{MnO}$ were experimentally measured at the temperature range between 1400 and $1700{ }^{\circ} \mathrm{C}$; the effect of various additions were studied thoroughly, and the findings were reported and also compared with those available in the literature. The effects of solid fraction in the slag as calculated by FactSage 7.2 were also considered for this estimation under different conditions. The results show the following:

(1) The softening, semi-spherical, and flow temperatures of the investigated BOF slags increase with the increasing $\mathrm{MgO}$ content from 2 to 8 mass $\%$ and decrease with the addition of $\mathrm{Al}_{2} \mathrm{O}_{3}$. The addition of $\mathrm{TiO}_{2}$ up to 5 mass $\%$ to $\mathrm{BOF}$ slag with 8 mass $\%$ of $\mathrm{MgO}$ reduces all three characteristic temperatures of the melting behavior. Three characteristic temperatures decrease with the addition of 1.8 mass $\%$ of $\mathrm{TiO}_{2}$ to BOF slag with 2 mass $\%$ of $\mathrm{MgO}$ and increase with the addition up to 5 mass $\%$ of $\mathrm{TiO}_{2}$.

(2) The viscosity of the BOF slag increases with the increasing of $\mathrm{MgO}$ content from 2 to 8 mass $\%$.

(3) In the slags with 2 mass $\% \mathrm{MgO}$, the addition of $\mathrm{Al}_{2} \mathrm{O}_{3}$ increases the viscosity in the liquid-determined region, and it decreases viscosity at the low temperatures. In slags with 8 mass $\%$ $\mathrm{MgO}, \mathrm{Al}_{2} \mathrm{O}_{3}$ reduces the viscosity in all the temperature ranges.

(4) In slags with 2 mass \% MgO, viscosity at higher temperatures above $1600{ }^{\circ} \mathrm{C}$ does not depend on the $\mathrm{TiO}_{2}$ content. With a decrease in temperature, the addition of $\mathrm{TiO}_{2}$ first reduces and then increases the viscosity. In slags with 8 mass $\% \mathrm{MgO}$, the addition of $\mathrm{TiO}_{2}$ reduces the viscosity in the liquid-determined region. Then, when the temperature drops, the viscosity increases with the addition of $\mathrm{TiO}_{2}$.

(5) In the slags with 2 mass $\% \mathrm{MgO}$, the addition of $\mathrm{MnO}$ does not affect the viscosity at a higher temperature range, in the liquid-determined region. In the slags with 8 mass $\% \mathrm{MgO}$, the addition of $\mathrm{MnO}$ reduces the viscosity in the high-temperature region. When the temperature decreases, the viscosity of the slags with 2 and 8 mass $\% \mathrm{MgO}$ increases with the addition of $\mathrm{MnO}$.

(6) The activation energies of the investigated BOF slags lies between 8 and $44 \mathrm{~kJ} / \mathrm{mol}$ in the liquid-determined region.

Author Contributions: Conceptualization, A.K.S. and O.V.; software, A.K.S.; validation, O.V.; formal analysis, O.V.; investigation (measurement, sample preparation), O.K., I.K., S.C.; writing-original draft preparation, O.V.; writing-review and editing, A.K.S., S.C., I.K.; funding acquisition, A.K.S, O.V. All authors have read and agreed to the published version of the manuscript.

Funding: This research was funded by German-Indian-PPP-DAAD-DST-program, Grand 5789471.

Acknowledgments: Financial support by German-Indian-PPP-DAAD-DST-program, Grand 5789471, is gratefully acknowledged.

Conflicts of Interest: The authors declare no conflict of interest.

\section{References}

1. Urbain, G.; Bottinga, Y.; Richet, P. Viscosity of liquid silica, silicates and alumino-silicates. Geochim. Cosmochim. Acta 1982, 46, 1061-1072. [CrossRef]

2. Jia, R.; Deng, L.; Yun, F.; Li, H.; Zhang, X.; Jia, X. Effects of $\mathrm{SiO}_{2} / \mathrm{CaO}$ ratio on viscosity, structure, and mechanical properties of blast furnace slag glass ceramics. Mater. Chem. Phys. 2019, 233, 155-162. [CrossRef]

3. Kondratiev, A.; Jak, E. Modelling of viscosities of the Pertly Crystallized Slags in the $\mathrm{Al}_{2} \mathrm{O}_{3}-\mathrm{CaO}-\mathrm{FeO}-\mathrm{SiO} \mathrm{O}_{2}$ system. Metall. Mater. Trans. B 2001, 32, 1027-1032. [CrossRef]

4. Kondratiev, A.; Jak, E. A Quasi chemical viscosity model for fully liquid slags in the $\mathrm{Al}_{2} \mathrm{O}_{3}-\mathrm{CaO}-\mathrm{FeO}-\mathrm{SiO} 2$ system. Metall. Mater. Trans. B 2005, 36, 623-638. [CrossRef]

5. Suzuki, M.; Jak, E. Quasi-Chemical Viscosity Model for Fully Liquid Slag in the $\mathrm{Al}_{2} \mathrm{O}_{3}-\mathrm{CaO}-\mathrm{MgO}-\mathrm{SiO} 2$ System. Part II: Evaluation of Slag Viscosities. Metall. Mater. Trans. B 2013, 44, 1451-1465. [CrossRef]

6. Suzuki, M.; Jak, E. Quasi-Chemical Viscosity Model for Fully Liquid Slag in the $\mathrm{Al}_{2} \mathrm{O}_{3}-\mathrm{CaO}-\mathrm{MgO}-\mathrm{SiO} 2$ System-Part I: Revision of the Model. Metall. Mater. Trans. B 2013, 44, 1435-1450. [CrossRef]

7. Shen, X.; Chen, M.; Wang, N. A Structurally-based Viscosity Model of the Fully Liquid Slags in the $\mathrm{CaO}-\mathrm{MgO}-\mathrm{Al}_{2} \mathrm{O}_{3}-\mathrm{FeO}-\mathrm{SiO}_{2}$ System. ISIJ Int. 2019, 59, 1940-1946. [CrossRef] 
8. Mills, K.C.; Sridhar, S. Viscosities of ironmaking and steelmaking slags. Ironmak. Steelmak. 1999, 26, $262-268$. [CrossRef]

9. Shankar, A.; Goernerup, M.; Lahiri, A.K.; Seetharaman, S. Estimation of viscosity for blast furnace type slags. Ironmak. Steelmak. 2007, 34, 477-481. [CrossRef]

10. Shahbazian, F. Experimental studies of viscosities in the $\mathrm{CaO}-\mathrm{FeO}-\mathrm{SiO}_{2}-\mathrm{CaF}_{2}$ slags. Scand. J. Metall. 2001, 30, 302-308. [CrossRef]

11. Kozhukhov, A.A. Influence of the viscosity and melting point of converter slag on its foaming behaviour. Steel Transl. 2014, 44, 136-139. [CrossRef]

12. Liu, Z.; Pandelaers, L.; Blanpain, B.; Guo, M. Viscosity of Heterogeneous Silicate Melts: A Review. Metall. Mater. Trans. B 2018, 49, 2469-2486. [CrossRef]

13. Jiao, K.; Zhang, J.; Liu, Z.; Chen, C. Effect of $\mathrm{MgO} / \mathrm{Al}_{2} \mathrm{O}_{3}$ Ratio on Viscosity of Blast Furnace Primary Slag. High Temp. Mater. Process. 2019, 38, 354-361. [CrossRef]

14. Kondtariev, A.; Hayes, P.C.; Jak, E. Development of a Quasi-chemical Viscosity Model for Fully Liquid Slags in the $\mathrm{Al}_{2} \mathrm{O}_{3}-\mathrm{CaO}-{ }^{\prime} \mathrm{FeO}{ }^{\prime}-\mathrm{MgO}-\mathrm{SiO}_{2}$ System. Part 3. Summary of the Model Predictions for the $\mathrm{Al}_{2} \mathrm{O}_{3}-\mathrm{CaO}-\mathrm{MgO}-\mathrm{SiO}_{2}$ System and Its Sub-systems. ISIJ Int. 2008, 48, 7-16.

15. Chen, M.; Zhao, B. Viscosity Measurements of $\mathrm{SiO}_{2}-{ }^{\prime \prime} \mathrm{FeO}$ "-CaO System in Equilibrium with Metallic Fe. Metall. Mater. Trans. B 2015, 46,577-584. [CrossRef]

16. Sukenaga, S.; Nagahisa, T.; Gonda, Y.; Saito, N.; Nakashima, J.; Nakashima, K. Viscosity of Iron Oxides Containing Multicomponent Slags. Tetsu-Hagane 2010, 96, 469-474. [CrossRef]

17. Lee, Y.S.; Min, D.J.; Jung, S.M.; Yi, S.H. Influence of Basicity and FeO Content on Viscosity of Blast Furnace Type Slags Containing FeO. ISIJ Int. 2004, 44, 1283-1290. [CrossRef]

18. Liu, S.; Wang, L.; Chou, K.C. Viscosity measurement of $\mathrm{FeO}-\mathrm{SiO}_{2}-\mathrm{V}_{2} \mathrm{O}_{3}-\mathrm{TiO}_{2}$ slags in the temperature range of 1644-1791K and modelling by using ion-oxygen parameter. Ironmak. Steelmak. 2018, 45, 641-647. [CrossRef]

19. Huang, B.; Zhu, M.; Zhong, Y.; Zhang, A.; Lin, T. 10th International Symposium on High-Temperature Metallurgical Processing. In The Minerals, Metals Materials Series; Springer: Heidelberg, Germany, 2019; pp. 109-116.

20. Liu, Z.; Dekkers, R.; Blanpain, B.; Guo, M. Experimental Study on the Viscosity of Stainless Steelmaking Slags. ISIJ Int. 2019, 59, 404-411. [CrossRef]

21. Zhang, G.; Wang, N.; Chen, M.; Li, H. Viscosity and Structure of $\mathrm{CaO}-\mathrm{SiO}_{2}-{ }^{\text {"FeO }} \mathrm{Fe}^{\prime}-\mathrm{Al}_{2} \mathrm{O}_{3}-\mathrm{MgO}$ System during Iron-Extracting Process from Nickel Slag by Aluminum Dross. Part 1: Coupling Effect of "FeO" and $\mathrm{Al}_{2} \mathrm{O}_{3}$. Steel Res. Int. 2018, 89, 1800272. [CrossRef]

22. Zhang, G.; Wang, N.; Chen, M.; Wang, Y. Viscosity and Structure of $\mathrm{CaO}-\mathrm{SiO}_{2}-{ }^{\text {" }} \mathrm{FeO}$ ” $-\mathrm{Al}_{2} \mathrm{O}_{3}-\mathrm{MgO}_{\text {System }}$ during Iron-Extracting Process from Nickel Slag by Aluminum Dross. Part 2: Influence of $\mathrm{Al}_{2} \mathrm{O}_{3} / \mathrm{SiO}_{2}$ Ratio. Steel Res. Int. 2018, 89, 1800273. [CrossRef]

23. Jiao, K.; Zhang, J.; Wang, Z.; Liu, Y.; Xu, R. Melting Featured and Viscosity of $\mathrm{TiO}_{2}$-Containing Primary Slag in a Blast Furnace. High Temp. Mater. Process. 2018, 37, 149-156. [CrossRef]

24. Jiao, K.; Zhang, J.L.; Wang, Z.Y.; Chen, C.C.; Liu, Y.X. Effect of $\mathrm{TiO}_{2}$ and $\mathrm{FeO}$ on the Viscosity and Structure of Blast Furnace Primary Slags. Steel Res. Int. 2017, 88, 201600296. [CrossRef]

25. Li, T.; Sun, C.; Song, S.; Wang, Q. Influences of $\mathrm{A} 12 \mathrm{O} 3$ and $\mathrm{TiO} 2$ Content on Viscosity and Structure of $\mathrm{CaO}-8 \% \mathrm{MgO}-\mathrm{Al}_{2} \mathrm{O}_{3}-\mathrm{SiO}_{2}-\mathrm{TiO}_{2}-5 \% \mathrm{FeO}$ Blast Furnace Primary Slag. Metals 2019, 9, 743. [CrossRef]

26. Li, T.; Sun, C.; Song, S.; Wang, Q. Roles of $\mathrm{MgO}$ and $\mathrm{Al}_{2} \mathrm{O}_{3}$ on the Viscous and Structural Behavior of Blast Furnace Primary Slag, Part 1: C/S = 1.3 Containing $\mathrm{TiO}_{2}$. Metals 2019, 9, 866. [CrossRef]

27. Kim, J.R.; Lee, Y.S.; Min, D.J.; Jung, S.M.; Yi, S.H. Influence of $\mathrm{MgO}$ and $\mathrm{Al}_{2} \mathrm{O}_{3}$ Contents on Viscosity of Blast Furnace Type Slags Containing FeO. ISIJ Int. 2004, 44, 1291-1297. [CrossRef]

28. Seok, S.H.; Jung, S.M.; Lee, Y.S.; Min, D.J. Viscosity of Highly Basic Slags. ISIJ Int. 2007, 47, 1090-1096. [CrossRef]

29. Shen, X.; Chen, M.; Wang, N.; Wang, D. Viscosity Property and Melt Structure of CaO-MgO- $\mathrm{SiO}_{2}-\mathrm{Al}_{2} \mathrm{O}_{3}-\mathrm{FeO}$ Slag System. ISIJ Int. 2019, 59, 9-15. [CrossRef]

30. Liu, Z.; Blanpain, B.; Guo, M. Viscosity of Partially Crystallized BOF Slag. In 7th International Symposium on High-Temperature Metallurgical Processing; Springer: Cham, Switzerland, 2016; pp. 263-269. 
31. Liu, Z.; Pandelaers, L.; Jones, P.T.; Blanpain, B. Effect of $\mathrm{Al}_{2} \mathrm{O}_{3}$ and $\mathrm{SiO}_{2}$ Addition on the Viscosity of BOF Slag. In Advances in Molten Slags, Fluxes, and Salts: Proceedings of the 10th International Conference on Molten Slags, Fluxes and Salts; Springer: Cham, Switzerland, 2016; pp. 439-446.

32. Liu, Z.; Chen, L.; Blanpain, B.; Guo, M. Effect of Crystallization on the Abrupt Viscosity Increase during the Slag Cooling Process. ISIJ Int. 2018, 58, 1972-1978. [CrossRef]

33. Kondratiev, A.; Hayes, P.C.; Jak, E. Development of a Quasi-chemical Viscosity Model for Fully Liquid Slags in the $\mathrm{Al}_{2} \mathrm{O}_{3}-\mathrm{CaO}-{ }^{\prime} \mathrm{FeO}-\mathrm{MgO}-\mathrm{SiO}_{2}$ System. Part 2. A Review of the Experimental Data and the Model Predictions for the $\mathrm{Al}_{2} \mathrm{O}_{3}-\mathrm{CaO}-\mathrm{MgO}, \mathrm{CaO}-\mathrm{MgO}-\mathrm{SiO}_{2}$ and $\mathrm{Al}_{2} \mathrm{O}_{3}-\mathrm{MgO}-\mathrm{SiO}_{2}$ Systems. ISIJ Int. 2006, 46, 368-374. [CrossRef]

34. Rahimi, R.; Pekker, P.; Biermann, H.; Volkova, O.; De Cooman, B.C.; Mola, J. Volumetric changes associated with B2-(Ni,Fe)Al dissolution in an Al-alloyed ferritic steel. Mater. Des. 2016, 111, 640-645. [CrossRef]

35. Wendler, M.; Hauser, M.; Eckner, R.; Weiß, A.; Volkova, O.; Mola, J. Design neuartiger ultrahochfester CrMnNi-C-N-Stahlgusslegierungen mit erhoehter Plastizitaet. In Freiberger Forschungshefte, Metallurgisches Kolloquium zu Ehren von Prof. Dieter Janke, 67. Berg- und Huettenmaennischer Tag; Technical University Bergakademie Freiberg: Freiberg, Germany, 2016; pp. 17-25.

36. Dubberstein, T.; Jahn, A.; Lange, M.; Heller, H.P.; Scheller, P.R. Interfacial Reaction between Iron-Based Alloys and Polycrystalline a- $\mathrm{Al}_{2} \mathrm{O}_{3}$. Steel Res. Int. 2014, 85, 1220-1228. [CrossRef]

37. Chuang, H.C.; Hwang, W.S.; Liu, S.H. Effects of Basicity and FeO Content on the Softening and Melting Temperatures of the $\mathrm{CaO}-\mathrm{SiO}_{2}-\mathrm{MgO}-\mathrm{Al}_{2} \mathrm{O}_{3}$ Slag System. Mater. Trans. 2009, 50, 1448-1456. [CrossRef]

38. Standard, G. DIN51730 (2019-12-00.); Beuth Verlag GmbH: Berlin, Germany, 2019.

39. Heller, H.P.; Hoetzel, M.; Lychatz, B.; Haustein, N. Avoidance of Calibrating Errors with Viscosity Measurements of Metallurgical Slags. Steel Res. Int. 2013, 84, 982-990. [CrossRef]

40. Chebykin, D.; Heller, H.P.; Dubberstein, T.; Korobeinikov, I.; Volkova, O. Viscosity Measurement of Slags using Rotating Bob and Vibrating Finger Viscometer. ISIJ Int. 2017, 57, 1319-1326. [CrossRef]

41. Schuermann, E.; Schmoele, P.; Kolm, I. Verlauf der Kalksaetigung im System $\mathrm{FeO}-\mathrm{Fe}_{2} \mathrm{O}_{3}-\mathrm{CaO}-\mathrm{SiO}_{2}-\mathrm{P}_{2} \mathrm{O}_{5}-\mathrm{MgO}-\mathrm{MnO}$ beim Gleichgewicht mit einer Eisenschmelze. Steel Res. 1986, 56, 369-377. [CrossRef]

42. Iida, T.; Sakai, H.; Kita, Y.; Murakami, K. Equation for estimating viscosities of industrial mold fluxes. High Temp. Materials. Process. 2000, 19, 153-164. [CrossRef]

43. Urbain, G. Viscosity estimation of slags. Steel Res. 1987, 57, 111-116. [CrossRef]

44. Riboud, P.V.; Roux, Y.; Lucas, L.D.; Gaye, H. Improvement of continuous casting powders. Int. Steel Met. Mag. 1981, 19, 859-869. 